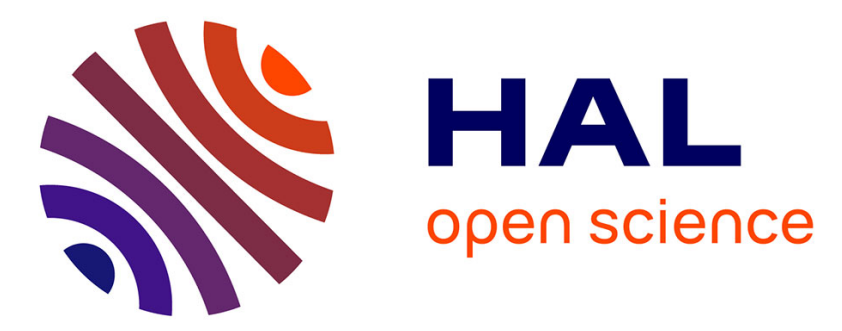

\title{
Structural characterization of SiN-carbon nanotube interfaces by transmission electron microscopy
}

Csaba Balázsia, Katarína Sedláčková, Zsolt Czigány

\section{To cite this version:}

Csaba Balázsia, Katarína Sedláčková, Zsolt Czigány. Structural characterization of SiN-carbon nanotube interfaces by transmission electron microscopy. Composites Science and Technology, 2008, 68 (6), pp.1596. 10.1016/j.compscitech.2007.11.009 . hal-00499003

\section{HAL Id: hal-00499003 https://hal.science/hal-00499003}

Submitted on 9 Jul 2010

HAL is a multi-disciplinary open access archive for the deposit and dissemination of scientific research documents, whether they are published or not. The documents may come from teaching and research institutions in France or abroad, or from public or private research centers.
L'archive ouverte pluridisciplinaire HAL, est destinée au dépôt et à la diffusion de documents scientifiques de niveau recherche, publiés ou non, émanant des établissements d'enseignement et de recherche français ou étrangers, des laboratoires publics ou privés. 


\section{Accepted Manuscript}

Structural characterization of $\mathrm{Si}_{3} \mathrm{~N}_{4}$-carbon nanotube interfaces by transmission electron microscopy

Csaba Balázsia, Katarína Sedlá čková, Zsolt Czigány

PII: S0266-3538(07)00467-8

DOI: 10.1016/j.compscitech.2007.11.009

Reference: CSTE 3916

To appear in: Composites Science and Technology

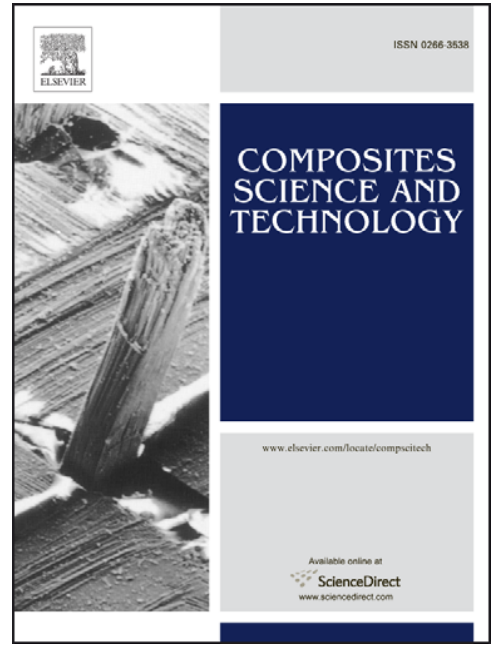

Received Date: $\quad 23$ September 2007

Revised Date: $\quad 30$ October 2007

Accepted Date: $\quad 16$ November 2007

Please cite this article as: Balázsia, C., Sedlá čková, K., Czigány, Z., Structural characterization of $\mathrm{Si}_{3} \mathrm{~N}_{4}$-carbon nanotube interfaces by transmission electron microscopy, Composites Science and Technology(2007), doi: 10.1016/ j.compscitech.2007.11.009

This is a PDF file of an unedited manuscript that has been accepted for publication. As a service to our customers we are providing this early version of the manuscript. The manuscript will undergo copyediting, typesetting, and review of the resulting proof before it is published in its final form. Please note that during the production process errors may be discovered which could affect the content, and all legal disclaimers that apply to the journal pertain. 


\title{
Structural characterization of $\mathrm{Si}_{3} \mathrm{~N}_{4}$-carbon nanotube interfaces by transmission electron microscopy
}

\author{
Csaba Balázsi* ${ }^{* 1}$, Katarína Sedláčková ${ }^{2}$ Zsolt Czigány ${ }^{2}$ \\ ${ }^{1}$ Ceramics and Composites Laboratory, Research Institute for Technical Physics and \\ Materials Science, Konkoly-Thege M. út 29-33, 1121 Budapest, Hungary \\ ${ }^{2}$ Thin Film Physics Laboratory, Research Institute for Technical Physics and Materials \\ Science, Konkoly-Thege M. út 29-33, 1121 Budapest, Hungary
}

Corresponding author: Csaba Balázsi, Phone: +36-1-392-2249, Fax: +36-1-392-2226 E-mail:balazsi@mfa.kfki.hu

\section{Introduction}

In recent years, ceramic materials with combination of carbon nanotubes (CNTs) have been intensive studied for their general potential applications [1-3]. Composites prepared by combining CNTs with brittle ceramics can impart some of the attractive mechanical properties of the carbon nanotubes to the resulting matrices. Ma et al. incorporated 10 vol.\% multiwall carbon nanotubes (MWCNTs) into SiC, however only a marginal increase in bend strength and toughness over $\mathrm{SiC}$ ceramics without MWCNTs was found [4]. One of the key problems of composite processing that still persist is the homogeneous dispersion of CNTs throughout the matrix. For this reason, to increase the dispersion grade of CNTs in ceramic matrix we performed high efficient ultrasonic homogenization and milling processes, or functionalization of carbon 
nanotubes has been applied [3,5]. Another interesting dispersion method is given by An et al. [6]. In this case, the CNT-reinforced ceramic composites are realized by using polymer derived ceramics (PDCs), which assures the desired dispersion grades in liquid-phase precursors just prior to pyrolysis. A colloidal processing as an efficient dispersing tool has also been proposed by Sun et al. [7]. In order to effectively utilize the CNTs it is crucial to retain CNTs intact in the composites and to optimize the interconnection between CNTs and the matrix to achieve load and current transition. In a recent study, Vasiliev et al. presented some new results on grain boundaries and nanotube orientation which resulted between 10 vol.\% single wall carbon nanotubes (SWCNTs) in $\mathrm{Al}_{2} \mathrm{O}_{3}$ ceramic [8].

In this work the study and characterization of silicon nitride/CNTs interfaces by transmission and high resolution microscopy will be presented.

\section{Experimental}

\subsection{Preparation of composites}

The main starting powder used in experiments was $\alpha-\mathrm{Si}_{3} \mathrm{~N}_{4}$ (Ube, SN-ESP). We used the sintering aids in form of following powders $4 \mathrm{wt} \% \mathrm{Al}_{2} \mathrm{O}_{3}$ (Alcoa, A16) and $6 \mathrm{wt} \%$ $\mathrm{Y}_{2} \mathrm{O}_{3}$ (H.C. Starck, grade C). The powder mixtures together with $1 \mathrm{wt} \%$ MWCNTs were milled in ethanol in a planetary type ball mill (Fritsch), whereas the powders with $3 \mathrm{wt} \%$ MWCNTs were processed using a water based mixing in attritor (Union Process). The MWCNTs were prepared by CCVD method described in [5]. After 3h ball milling the powder mixtures and MWCNTs were introduced in an ethanol bath and sonicated for $1 \mathrm{~h}$. In the case of attrition milling a high rotation speed (4000 rpm) was used for 5 h. The powder mixtures were sieved, compacted and sintered by hot isostatic 
pressing (HIP, ABRA type). Sintering was performed at $1700^{\circ} \mathrm{C}$, in high purity nitrogen at $20 \mathrm{MPa}$, with $3 \mathrm{~h}$ holding time. The heating rate did not exceed $25^{\circ} \mathrm{C} / \mathrm{min}$.

\subsection{Characterization techniques}

The structure of ceramic composites was investigated by conventional transmission electron microscopy (TEM) using a Philips CM-20 (200 kV) microscope and by high resolution electron microscopy (HREM) using a JEOL $3010(300 \mathrm{kV})$ microscope. The elemental compositions were measured by Ge detector NORAN EDS (Energy Dispersive Spectrometer), attached to the CM-20 microscope.

\section{Results and Discussion}

\subsection{Silicon nitride ceramics with CNTs prepared by ball milling}

The starting powder mixtures consisted of $90 \mathrm{wt} \% \alpha-\mathrm{Si}_{3} \mathrm{~N}_{4}, 4 \mathrm{wt} \% \mathrm{Al}_{2} \mathrm{O}_{3}, 6 \mathrm{wt} \% \mathrm{Y}_{2} \mathrm{O}_{3}$ and 1wt $\%$ MWCNTs. Ball milling and ultrasonic agitation of powder mixtures assured a decent homogeneity. In our previous work [3], we characterized the starting powder mixtures by SEM. That study showed that the nanotubes have the diameter $\sim 20 \mathrm{~nm}$ and can reach $8 \div 10 \mu \mathrm{m}$ in length.

The HREM characterization of sintered silicon nitride with CNTs showed that there is a good contact between nanotubes and the surface of silicon nitride grains (Fig. 1). Nanotubes located in porosity enclosed within $\beta-\mathrm{Si}_{3} \mathrm{~N}_{4}$ grains are shown by the cross section TEM image (Fig. 1a). Selection area electron diffraction (SAED) with 3.5 $\AA$ A reflection maximum (typically for (002) graphite) confirmed the presence of CNTs between silicon nitride grains (Fig. 1).

\subsection{Silicon nitride ceramics with CNTs prepared by attrition milling}

In this case, starting powder mixtures consisted of $90 \mathrm{wt} \% \alpha-\mathrm{Si}_{3} \mathrm{~N}_{4}, 4 \mathrm{wt} \% \mathrm{Al}_{2} \mathrm{O}_{3}, 6$ $\mathrm{wt} \% \mathrm{Y}_{2} \mathrm{O}_{3}$ grains and $3 \mathrm{wt} \%$ MWCNTs addition. 
As revealed by TEM analysis, after milling by high efficient attritor, the ceramic powder comprised of $\sim 200 \mathrm{~nm}$ crystallites and dispersed CNTs (Fig. 2a). In Fig. 2b the dispersed nanotubes in ceramic powder mixture may be observed. The nanotube radius is $\sim 25 \mathrm{~nm}$. This observation is in correlation with our previous SEM study [3].

The structure of $\mathrm{Si}_{3} \mathrm{~N}_{4} / \mathrm{CNT}$ composite is shown in Fig. 3a and 4. The sample consisted of $\sim 300 \div 400 \mathrm{~nm}$ nanocrystalline grains. The CNTs were distributed into porosities and in the intergranular places (Fig. 3). The HREM investigation of $\beta-\mathrm{Si}_{3} \mathrm{~N}_{4} / \mathrm{CNTs}$ interface revealed the good ceramic-nanotube contact (Fig. 3b). Cross section TEM analysis showed, that the CNTs between $\beta-\mathrm{Si}_{3} \mathrm{~N}_{4}$ grains had similar orientation as in the case of ball milling; cross section and side view of CNTs are evidenced (Fig. 4). Similar observation was founded in $\mathrm{Al}_{2} \mathrm{O}_{3}$ ceramics with single-wall CNTs [8].

\section{Conclusions}

Silicon nitrides with ( 1 and $3 \mathrm{wt} \%$ ) CNTs were prepared by two milling techniques. The structure of composites and the interface between $\beta-\mathrm{Si}_{3} \mathrm{~N}_{4}$ crystallites and nanotubes were investigated by TEM and HREM. In the case of ball milling the average size of $\beta$ $\mathrm{Si}_{3} \mathrm{~N}_{4}$ crystallite grains $\sim 1 \mu \mathrm{m}$ and the pore size $\sim 500 \mathrm{~nm}$ were obtained after sintering. In comparison, in the case of attritor milling smaller grain size $\sim 300 \mathrm{~nm}$ and pore size $\sim$ $250 \mathrm{~nm}$ resulted after sintering. In both cases, the nanotubes were located mainly into porosities and in intergranular places. The CNTs had similar orientations, cross section and side view of CNTs have been observed.

\section{Acknowledgements}

This work was supported by OTKA Foundation (No. T63609). Thanks to Z. Kónya, I. Kiricsi for CNT preparation, to L. P. Biró, P. Arató for helpful discussions, to F. Wéber for composite preparation. Cs. Balázsi thanks for János Bolyai Research Grant. 


\section{ACCEPTED MANUSCRIPT}

\section{References}

[1] $\mathrm{X}$ Wang, NP Padture, $\mathrm{H}$ Tanaka, Nat. Mat., Contact-Damage-Resistant Ceramic/Single-Wall Carbon Nanotubes and Ceramic/Graphite Composites, 2004; 3: 539-544.

[2] J Tatami, T Katashima, K Komeya, T Meguro, T Wakihara, Electrically Conductive CNT-Dispersed Silicon Nitride Ceramics, J. Am. Ceram. Soc., 2005; 88 [10]: 28892895.

[3] C Balázsi, Z Kónya, F Wéber, LP Biró, P Arató, Mat. Sci. Eng. Preparation and characterization of carbon nanotube reinforced silicon nitride composites 2003; C 23/68: 1133-1138.

[4] RZ Ma, J Wu, BQ Wei, J Liang, DH Wu, J. Mater. Sci., Processing and properties of carbon nanotubes-nano-SiC ceramic, 1998; 33: 5243-5246.

[5] Z Kónya, I Vesselényi, K Niesz, A Kukovecz, A Demortier, A Fonseca, et al., Large scale production of short functionalized carbon nanotubes, Chem. Phys. Lett. 2002; 360: $429-435$.

[6] L An, W Xu, S Rajagopalan, C Wang, H Wang, Y Fan, et al. Carbon naotube reinforced polimer derived ceramic composites, Adv. Mat., 2004; 16, 22: 2037-2043.

[7] J Sun, L Gao, W Li, Colloidal Processing of Carbon Nanotube/Alumina Composites, Chem. Mater. 2002; 14, 5169.

[8] AL Vasiliev, R Poyato, NP Padture. Scripta Mater., Single-Wall Carbon Nanotubes at Ceramic Grain Boundaries 2007; 56: 461-463. 


\section{ACCEPTED MANUSCRIPT}

Fig.1

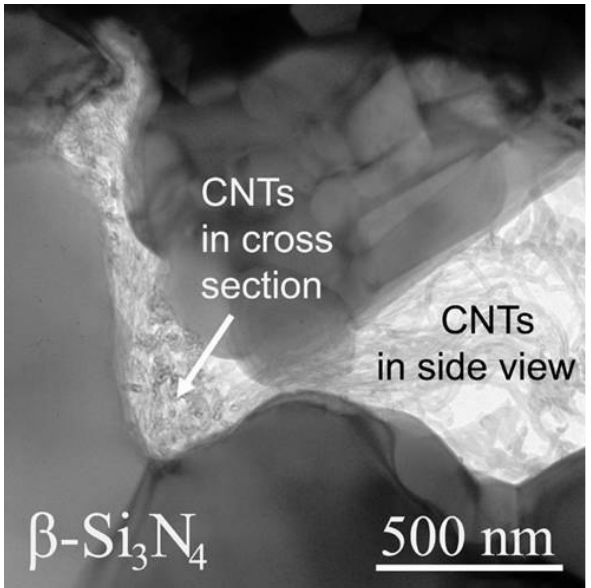

a)

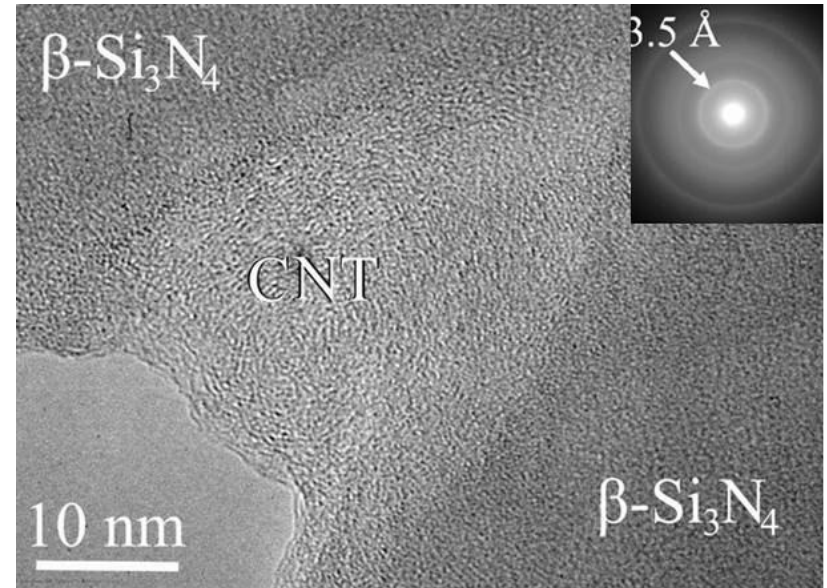

b)

Fig. 1 TEM images of sintered silicon nitride with 1 wt\% CNTs prepared by ball milling. a) TEM image of CNTs located in porosity reveals two different orientations. $b$ ) HREM image of sintered $\mathrm{Si}_{3} \mathrm{~N}_{4}$ shows CNTs embedded between two $\beta$-Si $\mathrm{S}_{3} \mathrm{~N}_{4}$ grains. The electron diffraction confirmed the presence of CNT. 


\section{ACCEPTED MANUSCRIPT}

Fig.2

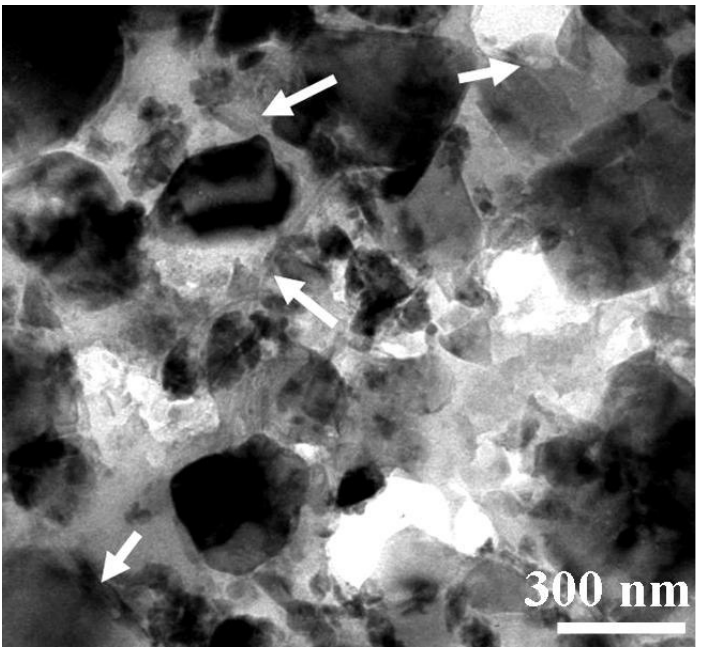

a)

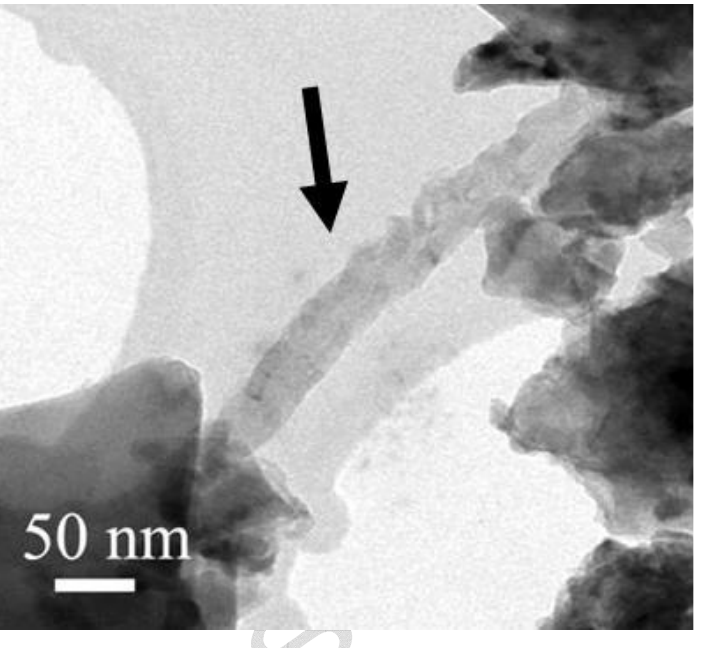

b)

Fig. 2 Bright field TEM images of starting powder mixture with 3 wt\% CNTs prepared by attrition milling. a) TEM image shows the CNTs (marked) between grains. b) The detail of CNT (marked) with $\sim 25 \mathrm{~nm}$ radius. 


\section{ACCEPTED MANUSCRIPT}

Fig.3

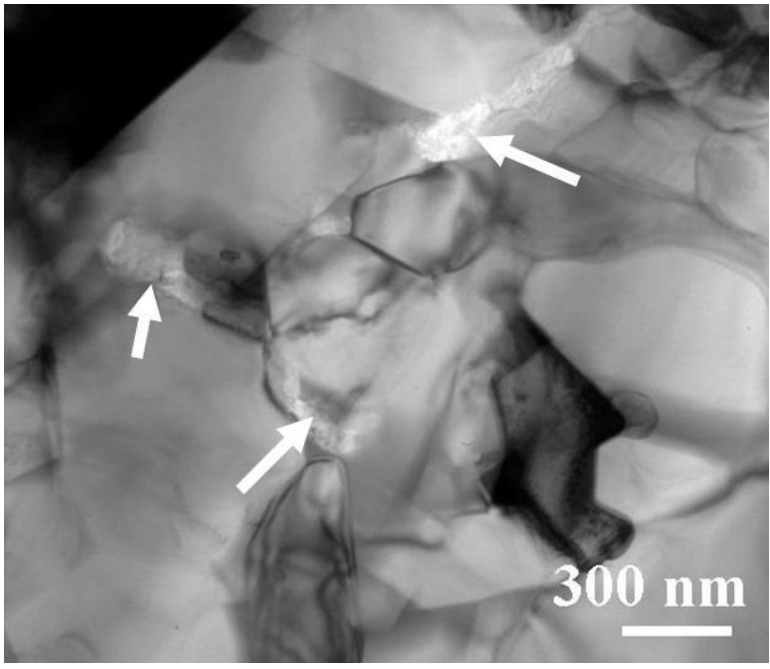

a)

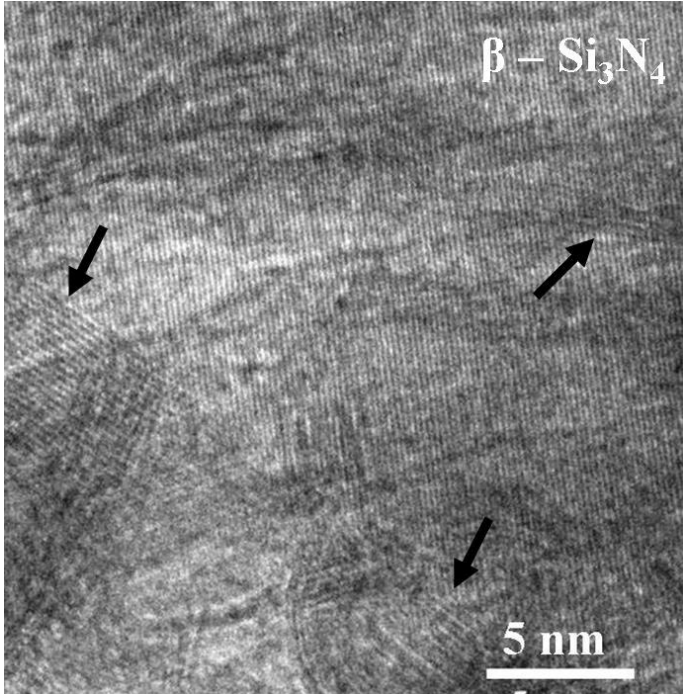

b)

Fig. 3 TEM images of sintered $\mathrm{Si}_{3} \mathrm{~N}_{4} / \mathrm{CNT}$ composite prepared by attrition milling. a) Cross-section bright field TEM image shows the CNTs located into porosities between $\beta-S_{3} N_{4}$ grains. b) HREM image shows the silicon nitride-CNTs interfaces. 


\section{ACCEPTED MANUSCRIPT}

Fig.4

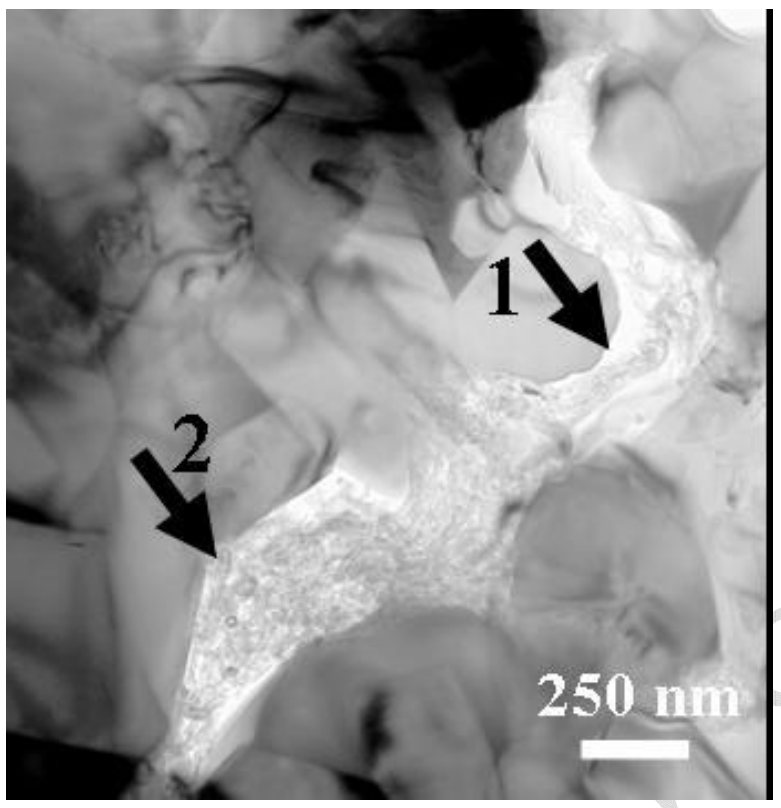

Fig. 4 Cross section TEM image of $\mathrm{Si}_{3} \mathrm{~N}_{4} / \mathrm{CNT}$ composite prepared by attrition milling. CNTs (marked) are located into porosity between $\mathrm{Si}_{3} \mathrm{~N}_{4}$ grains. 1. CNTs in side view, 2. CNTs in cross section view. 